\title{
The Anatomy of Cretaceous Pine Leaves.
}

\author{
BY \\ MARIE C. STOPES, D.Sc., PH.D., F.L.S.
}

AND

E. M. KERSHAW, M.Sc.

With Plates XXVII and XXVIII.

BFECT of the paper. To describe and illustrate the anatomy of two new species of Pine leaves from the Cretaceous of Japan, and to consider them in relation to those described from the Cretaceous of America and living forms.

Introductory remarks. The Coniferae are the only large group of plants of which it can be said that we have any considerable knowledge of the representatives in the Cretaceous period.

The interesting monograph on American Cretaceous Coniferae by Hollick and Jeffrey ('09), which brings together the numerous facts obtained and published already by these two authors, gives to the botanical world a solid basis for the construction of a conception of the characters of the group during Cretaceous times; but although a foundation is thus already laid, much remains to be done to complete our knowledge of the group, because the only source of anatomical information has hitherto been these American deposits. It seems to be worth while consequently to describe two new species of leaves of this affinity, which come from the Upper Cretaceous of another continent.

The specimens were obtained by one of us (M. C. S.) in Japan, in those mineral nodules which have been discovered recently, and open out the possibility of obtaining data of the anatomy of a mixed flora of Cretaceous age (see Stopes and Fujii, '10). The Gymnosperm leaves now to be described are both represented by isolated leaves, lying in the granular matrix of the nodule among other plant petrifactions, some of which were Gymnosperms, others Angiosperms and Ferns. But although the species are thus only known from isolated leaves, the petrifaction of their anatomy is so excellent that their specific characters can be determined satisfactorily.

[Annals of Botany, Vol. XXIV. No. XCIV. April, 1910.] 
Prepinus Japonicus, spec. nov.

Description of leaf. In the specimen we have a length of about $\mathrm{I} \cdot 2 \mathrm{~cm}$. of the leaf, in the course of which it does not appreciably vary in shape or diameter. The photograph on Pl. XXVII (Phot. I) represents the shape of the leaf in cross section. It appears to have been slightly crushed and contracted, as the assimilating tissue between the sclerenchyma and the transfusion tissue shows, but this crushing has altered the shape of the leaf very slightly, if at all. The greatest diameter of the leaf is $\mathrm{I} .5 \mathrm{~mm}$., and it has five sides.

In its shape the leaf closely resembles that of Prepinus statenensis as described by Jeffrey ('08). He notes (p. 208) that in its polygonal outline his leaf differs from any species of living Pinus, and he correlates this form with the fact that the leaves are in fascicles in numbers together, and not as in modern Pines in clusters of two, three, or five.

The epidermis is composed of small, squarish cells with very thick outer walls. The stomates are distributed on all sides of the leaf, and average about ten on the upper surface (the longest edge), six or seven on the two lower edges, and two or three on the lateral ones. They are of the normal Gymnosperm type, with sunken guard-cells placed at an oblique angle. In the intercellular space beneath them, fungal hyphae are to be seen in a good many cases in the specimen. Photograph 2, Pl. XXVII, shows an excellently preserved pair of guard-cells between the sclerenchyma patches on either side.

The hypodermal sclerenchyma is much broken up owing to the numerous stomates, and forms triangular groups with the point of the wedge towards the centre of the group (see P1.XXVII, Phots. I and 2, and Pl.XXVIII, Fig. I, $s c l$.$) . The individual cells are often extremely thick-walled, and their pit canals$ are often visible.

The assimilating tissue lies in small patches between the sclerenchyma and in a narrow zone outside the large central mass of transfusion tissue. In the sections this tissue is generally poorly preserved and crushed, but here and there its cells are visible, and show that the tissue was only five or six cells deep. In a few cells are indications that the walls were infolded as in the living Pinus, but this is not very clear.

The resin-ducts are two in number, laterally placed, slightly towards the upper side of the lateral edges of the leaf. They lie between the sclerenchyma and the transfusion tissue, almost filling the distance between them (see Pl. XXVIII, Fig. I, $g$ ). The duct is $0.07 \mathrm{~mm}$. in diameter, and is surrounded by thirteen to fourteen epithelial cells.

The vascular tissue, if the transfusion zone surrounding the bundle proper be included, bulks largely in the leaf. In this it closely resembles the American Prepinus. 
The actual bundle is double, and is surrounded entirely by a sclerized zone or sheath, which forms a tongue of hard tissue between the two strands (see Pl. XXVIII, Fig. I, v.sc.). These sclerized cells are small, and have not such thick walls as the hypodermic sclerenchyma. They are comparable to the sheath cells noted by Jeffrey ('08, Pl. XIV, Fig. I7) in his Cretaceous Hard Pines. They are not represented in his Prepinus as splitting the bundle, but otherwise seem much like the inner thick-walled sheath he describes. Whether it is right to compare this sheath with that described by Stopes ('03) for Cordaites, is a point about which we wish to reserve our opinion for the present.

The xylem in the two strands in our leaf is in small quantities, and the elements very small, $0.01 \mathrm{~mm}$. in diameter. The position of the phloem is apparent, but its cell-structure is not sufficiently well petrified for description. There is no indication of centripetal xylem or other unusual structure in the bundle.

The transfusion sheath is a broad zone of closely packed, fairly uniform cells (see $t$, Phot. I, Pl. XXVII, and Fig. I, Pl. XXVIII) about $0.05^{-0.06} \mathrm{~mm}$. in diameter. These fit closely together, have fairly thick walls, and appear to have been pitted, though only in a few cases are the pits still to be seen on their walls. There seems to have been no admixture of parenchyma cells with them. The outer zones of these cells may possibly be looked on as something of the nature of an endodermis : in the outermost row of cells the radial walls show an appearance suggestive of a slightly crushed endodermis, but the sheath is not a distinctive one.

Jeffrey ('08, p. 2II) notes the absence of an endodermis in his Prepinus, but his photographs do not absolutely determine this point, and the sections of the American Prepinus which Prof. F. W. Oliver of London University kindly lent us do not determine it either.

The reasons for placing our leaf in the genus Prepinus are as follows. Neither Jeffrey ('08) nor Hollick and Jeffrey ('09) give an actual diagnosis of their genus. When we pick out the more essential features from Jeffrey's description, however, they are : (I) the contour of the leaf, with five approximately plane surfaces, which differs from any known Pinus; (2) the number of leaves in a fascicle; (3) the two resin-canals, placed laterally; (4) the broad transfusion zone; (5) the sheath of thick cells round the bundle ; (6) the single bundle; (7) the large amount of centripetal wood in the bundle ; (8) the apparent absence of an endodermis ; (9) the presence of strong hypodermal isles beneath the epidermis.

Jeffrey places much stress on the shape of the leaf and the correlation of this with the number of leaves in a fascicle, in which this fossil genus differs from any type of Pinus. In his view regarding this feature we entirely concur, and think that for diagnostic features it is the most important. 
Our new species, from the description given above, will be seen to agree with Prepinus of Jeffrey in all of the nine points except as regards the absence of centripetal xylem and the splitting of the bundle by a tongue of the inner thick-walled sheath. These two features, though of great specific importance, do not appear to us to weigh sufficiently against all the other points of agreement to exclude our species from the genus Prepinus. Further, only leaves are known in both cases, and among fossils, until the plants are known fairly completely, it is always a pity to multiply genera. For the present then we include our species in the genus Prepinus of Jeffrey, and as he has given no diagnosis of the genus, we offer one now.

Prepinus, Jeffrey, 1908.

Gymnospermic foliage resembling Pinus, but with many leaves in fascicle. In section the leaf has five straight sides ; two lateral resin-ducts ; a large zone of transfusion tissue round the bundle which may or may not be divided; endodermis apparently absent; hypodermal sclerenchyma strands strongly marked.

Only species:-Prepinus statenensis, Jeffrey, described Annals of Botany, I908.

Our species separates itself from Jeffrey's through the absence of centripetal xylem, and the splitting of the bundle by the tongue of small thick-walled cells of the sheath.

\section{Prepinus japonicus, spec. nov.}

Leaf $\mathrm{I} .5 \mathrm{~mm}$. in diameter, central bundle split into two strands by the inner thick-walled sheath, no centripetal xylem recognizable.

Locality :-Upper Cretaceous, Japan. Collected by M. C. Stopes.

Type:-the figured slide has been presented to the British Museum, Department of Geology.

Discussion. The characteristic shape of our leaf, and its similarity to those leaves of Prepinus for which the feature was discussed by Jeffrey ('08, p. 208), seem sufficient ground for presuming that the leaves were in a multifoliar fascicle as they were in Prepinus statenensis. Our leaf is so characteristic and so remarkably like Jeffrey's in all important particulars save the absence of centripetal wood, that it seems to us to leave no doubt that it is truly of the same genus. It is only necessary to think of the living Cycads, in some species of which centripetal wood is found in the axis though it is absent from others, to realize that the point is hardly one of generic distinction. Our leaf comes from a geological horizon slightly more recent than the one which yielded the American specimens, and one might be tempted to present the view that the loss of the centripetal xylem was correlated with this. One might also point to the fact that the younger 
species approximated also to the modern type of Pinus in having a bundle, not separated actually into two as is frequent in the modern species, but split by the ingrowth of the inner thick-walled sheath.

For the moment, however, we find facts more attractive than theories, and will describe another species of leaf from this horizon.

Pinus yezoensis, sp. nov.

This species resembles much more closely the living Pinus than do any of those described by Jeffrey. As is seen in Phot. 3, Pl. XXVII, it is oval in section, with no straight side, and has a very well marked endodermis round the bundle and comparatively small transfusion zone. The leaf is about $\mathrm{I} \cdot \mathrm{I} \mathrm{mm}$. in diameter.

The epidermis consists of small, rather roundish cells, about $0.01 \mathrm{~mm}$. in diameter. The stomates are of the usual Gymnosperm type and are few in number.

The hypodermal sclerenchyma consists of a zone, two or three cells deep, of small cells with but slightly thickened walls.

The assimilating tissue of the leaf is well preserved, and consists of large cells $(0.08 \mathrm{~mm}$. in diam.) entirely like those of modern Pines, with curved walls folded into ridges projecting into the cell cavity ( $a$ in Phot. 4, Pl. XXVII, and Fig. 2, Pl. XXVIII).

The resin-canals are two in number, placed laterally and towards the upper side of the leaf. They lie immediately under the hypoderm; see $g$, Phot. 5, P1. XXVII. Each canal is about 0.035 in diameter, and is surrounded by a dozen epithelial cells which are roundish in outline, and very well petrified; see $e p$, Phot. 5 , Pl. XXVII.

The vascular tissue is surrounded by a large, well defined endodermis. This is seen clearly in Phots. 3 and 4, Pl. XXVII, and Fig. 2, Pl. XXVIII, $e n$, and is entirely similar to the endodermis in the living Pines.

The individual cells are large and oval, about 0.06 in diameter, and their radial walls fit together and appear to have been slightly thickened.

In view of Jeffrey's ('08, p. 216) statements about the American Cretaceous Pines, the exceedingly clear endodermis and the infolded walls of the mesophyll are both noteworthy features of this species.

A few sclerized cells occur within the endodermis, and these may possibly represent the remains of an inner thick-walled sheath such as was noted in Prepinus. There are one or two cells at the sides of the bundle which may have been transfusion cells, but the bulk of the tissue within the endodermis consists of the vascular tissues proper.

The xylem is arranged in radial series, a dozen or more rows of tracheides separated very widely by large medullary ray cells (see Phot. 4, P1. XXVII, and Fig. 2, P1. XXVIII, $m$ and $x$ ). The xylem appears to have been entirely centrifugal. 
The phloem is exceptionally well preserved for a fossil (see ph, Fig. 2, Pl. XXVIII, and Phot. 4, Pl. XXVII), and is relatively large in amount.

This leaf comes much nearer the living type of Pinus than do any described by Jeffrey or Hollick and Jeffrey. Hence, as they use the generic name of the living forms for their species, there appears no excuse for our creating a new genus to include our species, though on the whole we are not in favour of using the same generic name for living forms and fossil fragments. Only where the fossil plant is approximately known in its entirety is it wise to include it in a living group.

Our leaf, however, is so remarkably like the specialized and wellcharacterized Pinus leaf that the use of the modern generic name may be allowed.

\section{Pinus yezoensis, sp. nov.}

Leaf oval in outline, diameter about I mm. Central vascular strand large; radial wood strands separated by large rays; endodermal sheath very well marked; mesophyll with infolded walls; hypoderm slightly developed; resin-canals two, laterally placed.

Horizon.-Upper Cretaceous, Hokkaido (old Japanese name Yezo). Collected by M. C. Stopes.

Type :- the figured slide has been presented to the British Museum, Department of Geology.

Discussion.-The interest of this Cretaceous leaf lies in its complete likeness to the living types. Hollick and Jeffrey ('09, p. I3), in speaking of their Cretaceous species of Pinus, remark that 'these remains, when sufficiently well preserved, possess one feature which, in general, serves to distinguish all of the Cretaceous Pines thus far examined by us from those now living, and that is the very wide zone of transfusion tissue surrounding the leaf bundles.... The endodermal sheath separating the transfusion tissue from the mesophyll is also less clearly marked than in living Pines, or may be entirely absent.' In Jeffrey's ('08) fuller description of the leaves (p. 216) he enumerates four points in which the leaves of true Pines of the Staten Island deposits differ from those now living. They are: (1) 'In the better development of the transfusion elements round the bundle.' Our new species, from the Japanese Cretaceous, has less rather than more transfusion tissue than is common in living Pines. (2) 'In the differentiation of the transfusion elements into an inner sheath composed of elongated tracheidal elements, and an outer, much broader zone made up of more nearly isodiametric elements with thinner walls.' The Japanese species does not show such differentiation. The few slightly sclerized cells above and below the bundle might possibly be considered as remnants of the inner sheath, but this theoretical view entails its application to living Pinus, which the new fossil species resembles in this feature. 
(3) 'In the probable absence of an endodermis.' The Japanese fossil is seen to have a particularly well developed endodermis. (4) 'In the absence of infolding of the walls of the mesophyll.' The Japanese species has excellently preserved cells showing deep infolding of the cell-walls of the mesophyll.

It is clear, therefore, that the new species approximates extremely closely to the living type, and judging from the foliage, can be no more than specifically distinct from any living species. In the shape of the leaf, which is oval, with no straight edge such as is found in the Pines usually, we see a suggestion that there may have been only one leaf in the fascicle. The living $P$. monophylla is more circular in outline, however, and we would do no more than point out the suggestion offered by the shape of the leaf in $P$. yezoensis and note that it is also supported by the fact that there is a single bundle in $P$. yezoensis, as there is in $P$. monophylla, while there is usually a double one in the modern Pines with two or three needles in a fascicle.

These two new species from the Cretaceous show that the modern type of leaf in Pines was evolved by that time, and that at the same time and in the same place were living trees with the older type of Prepinus foliage.

We wish to tender our thanks to the Director of the Royal Gardens, Kew, for the supply of living species of Pine leaves which he kindly provided for comparison with the fossils.

\section{PAPERS QUOTED.}

Hollick, A., and Jeffrey, E. C. ('09): Studies of Cretaceous Coniferous Remains from Kreischerville, New York. Memoirs of the New York Botanical Garden, vol. iii, pp. I-76, Pl. I-XXIX, New York, May, I909.

Jeffrey, E. C. ('08): On the Structure of the Leaf in Cretaceous Pines. Ann. Bot., vol. xxii, no. lxxxvi, pp. 207-20, Pl. XIII and XIV, Oxford, I908.

Stopes, M. C. ('03): On the Leaf-Structure of Cordaites. New Phytol., vol. ii, pp. 9I-8, P1. IX, London, I903.

Stopes, M. C., and FuJII, K. ('10): Studies on the Structure and Affinities of Cretaceous Plants. Phil. Trans. Roy. Soc., vol. xx B, pp. I-9I, Pl. I-IX, London, 1910. 


\title{
DESCRIPTION OF PLATES XXVII AND XXVIII.
}

\author{
Illustrating the Paper by Dr. Stopes and Miss Kershaw on the Anatomy of Cretaceous \\ Pine Leaves.
}

\section{PLATE XXVII.}

Phot. I. Prepinus japonicus. Photograph of transverse section of the leaf, showing its five sides and general anatomy. scl., hypodermal sclerenchyma. g., resin-canals, two in number. $t$., transfusion tissue round the bundle.

Phot. 2. Prepinus japonicus. High power photograph of part of the leaf to show (st.) stomata lying between the groups of sclerenchyma $(s c l$.$) . t_{\text {. }}$, transfusion tissue.

Phot. 3. Pinus yezoensis. Photograph of a transverse section of the leaf, showing its oval outline and general anatomy.

Phot. 4. Pinus yezoensis. Enlarged view of part of the leaf. h., hypodermic sclerenchyma. $a$., assimilating cells, with infolded cells. en., endodermis. ph., phloem. $x$., xylem; note the large ray cells between the rows of tracheides.

Phot. 5. Part of the edge of the leaf enlarged to show the resin-canal $(g)$ lying at the edge below the hypoderm cells $(h$.$) . ep., epithelial cells of resin-canal. a., assimilating cells with$ infolded edges.

\section{PLATE XXVIII.}

Fig. I. Prepinus japonicus. Drawing of detail of leaf. scl., sclerenchyma patches. st., stomates. $g$, resin-canal. c.a., crushed assimilating tissue. v.sc., sclerized sheath of vascular strand. t., transfusion zone.

Fig. 2. Pinus yezoensis. Drawing of detail of leaf. a., assimilating cells. en., endodermis $x$., xylem. m., medullary ray cells. ph., phloem. 
Anrats of Botany,
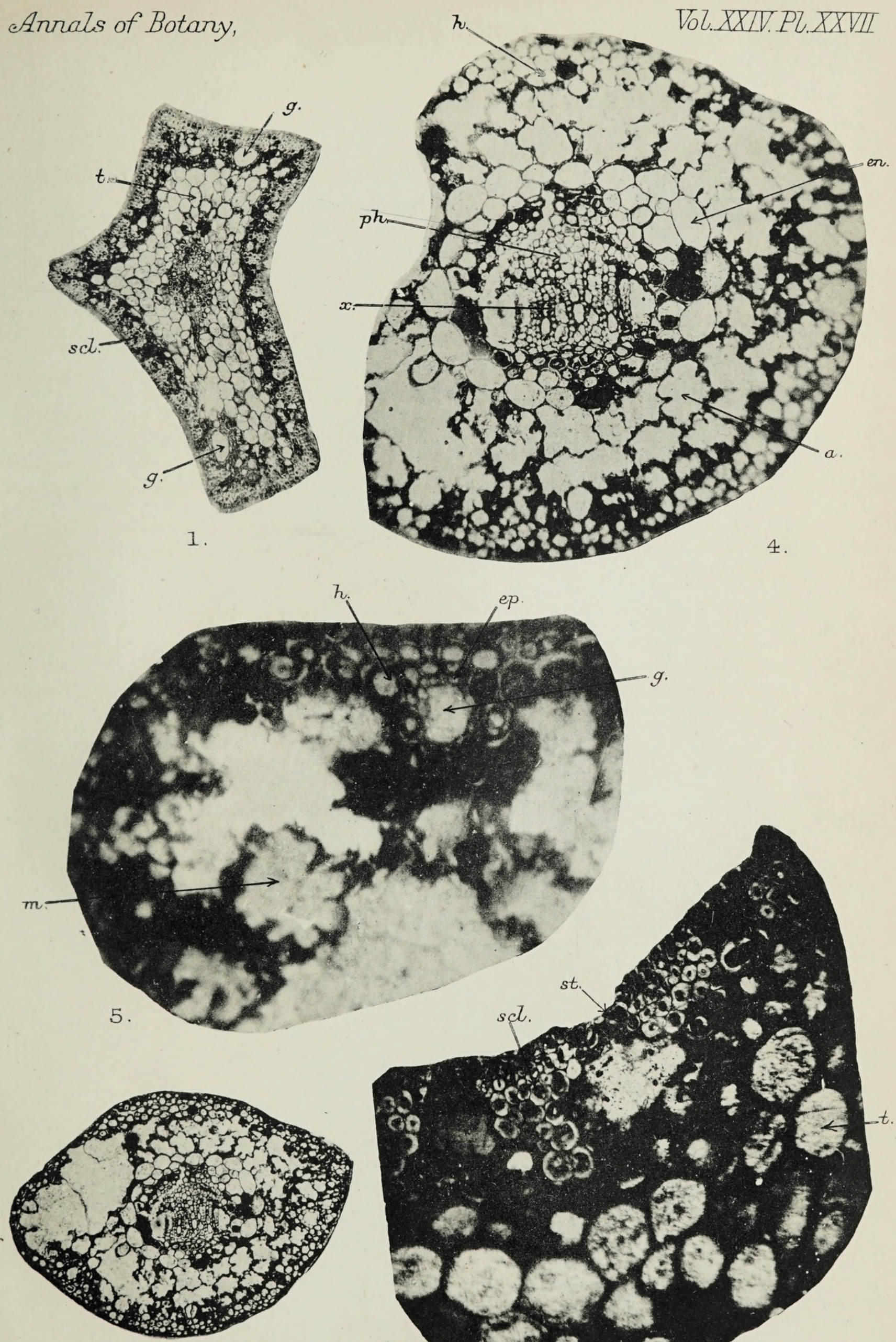

3

3.

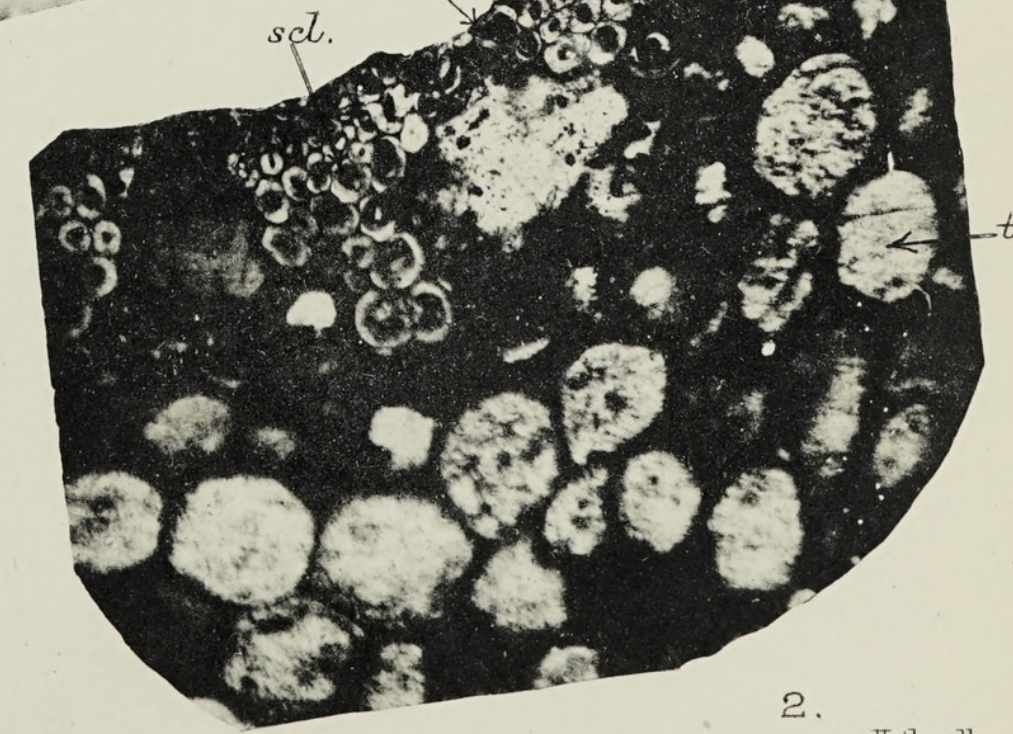

STOPES \& KERSHAW. - CRETACEOUS PINE LEAVES. 
Annals of Botany.

Vol.XXIV.PL.XXVIII.

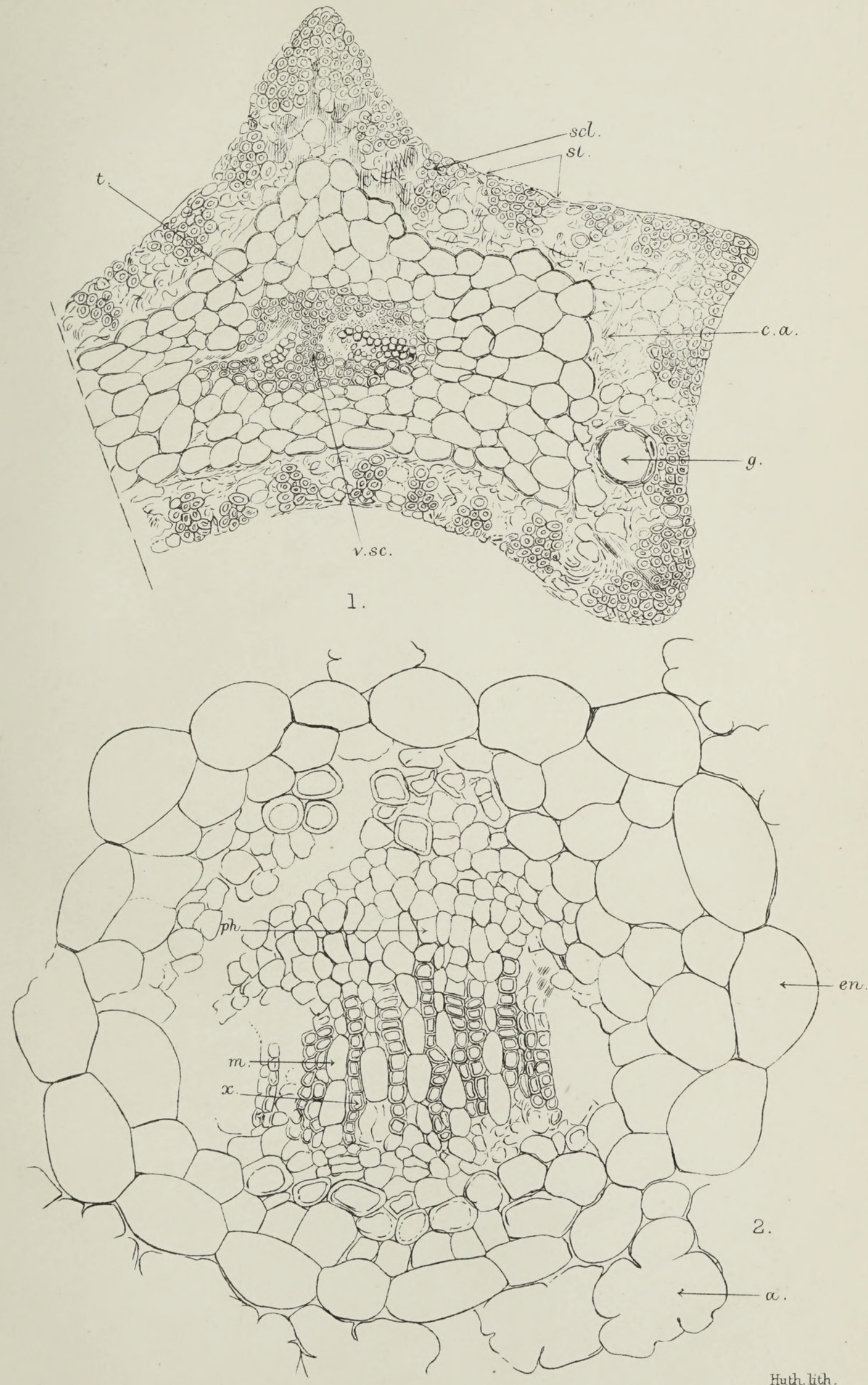

STOPES \& KERSHAW. - CRETACEOUS PINE LEAVES. 


\section{$2 \mathrm{BHL}$ Biodiversity Heritage Library}

Stopes, Marie Carmichael and Kershaw, Edith May. 1910. "The anatomy of cretaceous pine leaves." Annals of botany 24, 395-402. https://doi.org/10.1093/oxfordjournals.aob.a089275.

View This Item Online: https://www.biodiversitylibrary.org/item/262605

DOI: https://doi.org/10.1093/oxfordjournals.aob.a089275

Permalink: https://www.biodiversitylibrary.org/partpdf/319783

\section{Holding Institution}

New York Botanical Garden, LuEsther T. Mertz Library

\section{Sponsored by}

BHL-SIL-FEDLINK

\section{Copyright \& Reuse}

Copyright Status: Public domain. The BHL considers that this work is no longer under copyright protection.

This document was created from content at the Biodiversity Heritage Library, the world's largest open access digital library for biodiversity literature and archives. Visit BHL at https://www.biodiversitylibrary.org. 